\title{
(⿹

\section{Fyldig bok for den som kan litt fra før}

ANMELDELSER

\section{EIRIK SKOGVOLL}

Overlege, Anestesiavdelingen

St. Olavs hospital

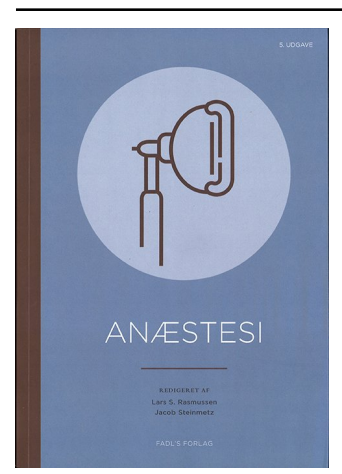

Lars S. Rasmussen, Jacob Steinmetz

Anæstesi

5. utg. 381 s, tab, ill. København: FADL’s forlag, 2020. Pris DKK 450

ISBN 978-87-93590-95-3

Kirurgisk anestesi ble i New England Journal of Medicine omtalt som et av det forrige årtusenets elleve viktigste medisinske gjennombrudd. Denne boka, som er skrevet på dansk, henvender seg til leger i spesialisering og sykepleiere som gir anestesi i Danmark i dag. Den oppsummerer på en oversiktlig måte hvordan faget praktiseres i Norden, og er skrevet av ikke mindre enn 37 danske anestesileger med bred klinisk erfaring.

Boka går bokstavelig talt rett på sak, med preoperativ vurdering. Den som leser bøker fra perm til perm og starter på side én, vil kanskje forvente en mer konvensjonell start med prinsipper for analgesi, søvn og muskelrelaksasjon. Disse kommer - bitvis - i de enkelte kapitlene.

Etter preoperativ vurdering beskrives generelle anestesiologiske prinsipper: bruk av ultralyd, monitorering, luftveishåndtering, anestesimidler, regional anestesi, væskebehandling og innledning av narkose. Dernest omtales spesielle pasientgrupper (barn, gravide, nyresyke osv.), etterfulgt av oppvåkning, komplikasjoner, postoperativ smertebehandling og teamarbeid. Til slutt omtales anestesilegens mer generelle oppgaver i forbindelse med resuscitering, traumer, intrakranielle katastrofer, sirkulasjonssvikt og respirasjonssvikt. Hvert kapittel innledes med en summarisk oversikt og slutter med spørsmål til diskusjon (noen også med «fasit»), som kan egne seg til både selvstudium og kollokvier. 
Boka har mange gode illustrasjoner i farger. De beste er i form av strektegninger, men det er også mange gode og illustrerende foto (f.eks. ultralyd til kanylering), selv om noen er blitt litt mørke i trykken. Verdt å nevne er at hemoglobin oppgis i enheten mmol/L - i Norge bruker vi fortsatt $\mathrm{g} / \mathrm{dL}(10 \mathrm{~g} / \mathrm{dL}$ tilsvarer $6,21 \mathrm{mmol} / \mathrm{L})$.

Dette er blitt en solid og oppdatert lærebok. Den er praktisk orientert og med betydelig bredde, faglig tyngde og relevans. Min eneste innvending er at boka er «stykkevis og delt», og kanskje ikke like egnet for de som er ferske i faget. Man må nok ha litt erfaring og overblikk for å sette sammen detaljene til en helhet. Men som noe i nærheten av en nordisk «metodebok» i anestesi synes jeg den har blitt svært vellykket.

Publisert: 14. desember 2020. Tidsskr Nor Legeforen. DOI: 10.4045/tidsskr.20.0794

(C) Tidsskrift for Den norske legeforening 2020. Lastet ned fra tidsskriftet.no 